\title{
Comparison of Skin Graft for the Defect of the Radial Forearm Free Flap
}

\author{
Joon Kyoo Lee $\mathbb{D}$, Sung Ho Yoon, Tae Gu Kang, Jae Gu Kim, Hee Young Kim, \\ Hye Rin Lim, Se Hyun Jeong, and Kyeong Suk Park \\ Department of Otolaryngology-Head and Neck Surgery, Chonnam National University Medical School and Hwasun Hospital, \\ Hwasun, Korea
}

\section{요측전완유리피판 결손 부위의 피부 이식에 관한 비교 연구 \\ 이준규·윤성호· 강태구· 김재구· 김희영· 임혜린· 정세현· 박경석 \\ 전남대학교 의과대학 화순전남대학교병원 이비인후과학교실}

\author{
Received February 20, 2019 \\ Revised April 30, 2019 \\ Accepted June 3, 2019 \\ Address for correspondence \\ Joon Kyoo Lee, MD, PhD \\ Department of Otolaryngology- \\ Head and Neck Surgery, \\ Chonnam National University \\ Medical School and \\ Hwasun Hospital, \\ 322 Seoyang-ro, Hwasun 58128, \\ Korea \\ Tel $+82-61-379-8190$ \\ Fax $+82-61-379-8199$ \\ E-mail joonkyoo@jnu.ac.kr
}

Background and Objectives This study compared two types of skin graft reconstruction for the defect of the radial forearm free flap.

Subjects and Method Ten cases of split-thickness skin graft (STSG) harvested from the thigh were analyzed. Also, ten cases of full-thickness skin graft (FTSG) harvest from the inguinal area applied with vacuum-assisted closure (VAC) system were analyzed.

Results The defect size of the radial forearm was increased more in the STSG group than in the FTSG group $(p<0.05)$. Skin grafts were recovered completely sooner in the FTSG group than in the STSG group although it was not statistically significant $(p=0.082)$. Five complications (pruritus, hypertrophic scar) were found in the donor site in the STSG group $(p<0.05)$. FTSG gave better scores according to the Vancouver Scar Scale in terms of pigmentation, pliability, and height $(p<0.05)$.

Conclusion FTSG harvested from the inguinal area with the application of VAC system has many advantages for the defect of the radial forearm free flap although it is usually used for smaller size defects than for STSGs.

Korean J Otorhinolaryngol-Head Neck Surg 2019;62(9):515-9

Key Words Forearm · Free tissue flaps · Reconstructive surgical procedures · Skin transplantation.

\section{서 론}

요측전완유리피판(radial forearm free flap, RFFF)은 구 강악안면 부위에서 가장 흔하고 널리 쓰이는 피판 중 하나이 다.) 이 피판의 단점 중 하나는 바로 요측전완 부위의 결손에 관한 문제이다. 결손 부위 재건을 위해 또 다른 수술 과정이 필요하며 이 외에도 수술 후 상처 치유의 문제, 기저부의 건 (tendon)의 노출, 감각 저하, 손목 신전의 문제 등이 보고되

This is an Open Access article distributed under the terms of the Creative Commons Attribution Non-Commercial License (https://creativecommons.org/licenses/by-nc/4.0) which permits unrestricted non-commercial use, distribution, and reproduction in any medium, provided the original work is properly cited.
고 있다. ${ }^{2)}$ 최근 Pabst 등은 은 1982년부터 2017년까지 RFFF 에 대한 메타분석을 시행하였는데, RFFF의 결손 부위를 재 건하는 방법을 크게 4개로 결론지었다. 즉 전층 피부 이식 (full-thickness skin grafts, FTSG), 부분층 피부 이식(splitthickness skin grafts, STSG), 피판을 거상하고 국소피판을 이용하여 재건하는 변형된 방법, 그리고 다른 방법들 (피부 확장기, 전외측대퇴피판, 동종 이식술 등)이었다.

요측전완 부위의 결손을 해결하기 위해 전통적으로 부분 층 피부 이식술이 쓰여 왔다. ${ }^{2,4-6)}$ 이 방법은 또 다른 공여부 (피부제공 부위)를 만들게 되는 단점이 있고 어떤 경우에는 수 주간에 걸쳐 환자에게 불편감을 준다. 반면, 전층 피부 이 
식은 공여부를 일차적으로 봉합하기 때문에 통증이 적고, 미용적으로 부분층 이식보다 결과가 더 좋다고 알려져 있다. ${ }^{8)}$ 부분층 이식이나 전층 이식이나 노출된 건이 주요 문제인데, ${ }^{5}$ 여기에 진공을 이용한 음압 상처 드레싱(vacuum-assisted closure)을 적용하면 건의 노출을 줄일 수 있다는 보고가 있 으며, 이것에 대해서는 의견이 분분하기도 하다. ${ }^{9-11}$

이에 저자들은 본 기관에서 시행된 요측전완유리피판의 결손 부위에 대한 두 가지 피부 이식 방법을 비교 분석하여, 그 결과를 토대로 향후 환자 치료에 적용하고자 하였다.

\section{대상 및 방법}

본 연구자 기관의 이비인후과에서 2014년 7월부터 2018년 8월까지 약 4년 동안 요측전완유리피판 재건술을 받고 그 결 손 부위에 대해서 피부 이식술을 받은 20 명의 환자를 대상으 로 하였다. 10 예는 부분층 피부 이식술을, 10 예는 진공을 이 용한 음압 상처 드레싱을 적용한 전층 피부 이식술을 받았다. 본 연구는 화순전남대학교병원 연구윤리 심의 위원회(Institutional Review Board, IRB)의 승인을 받았다(CNVHH2019-038).

부분층 이식술은 고식적인 방법으로서, 대퇴부에서 0.01

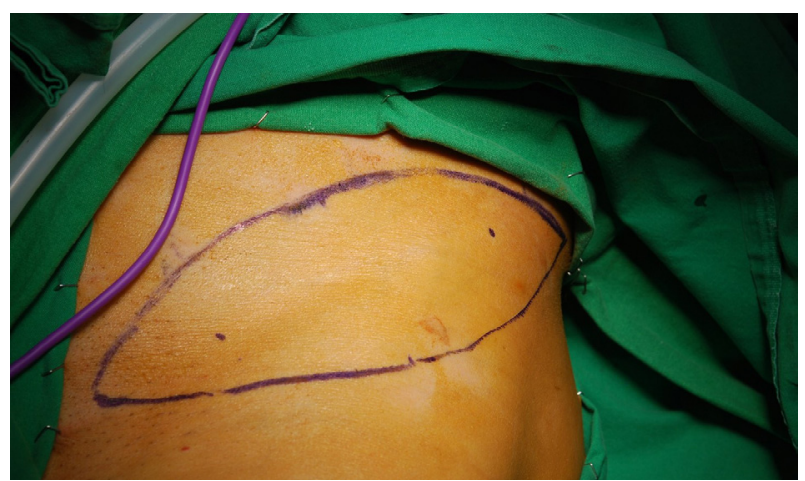

Fig. 1. The left inguinal area is designed for harvest for the fullthickness skin graft.

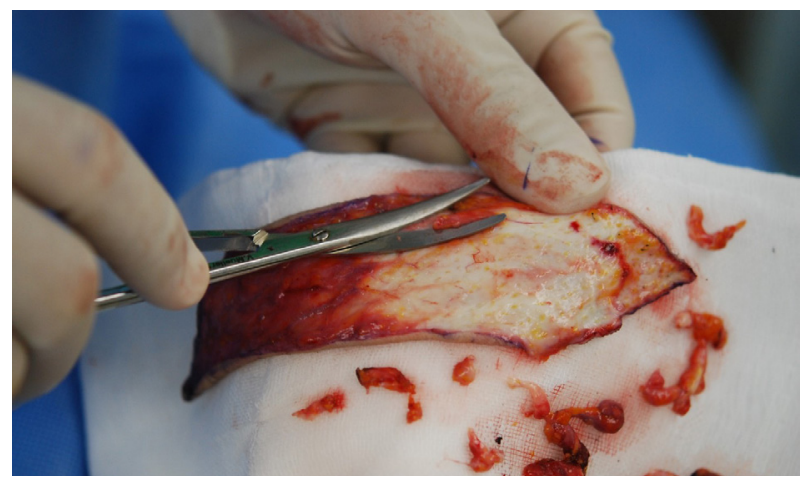

Fig. 2. The subcutaneous fat is being removed from the harvested skin for the successful anchoring to the forearm defect.
0.03 인치의 피부를 취해, 전완 결손 부위에 얹고, 주변부 봉 합과 몇 군데 중앙부 고정 봉합을 한 후, 정적인(static) 압박 드레싱을 시행하였다. 대퇴부의 피부 공여부는 이차적인 상 처 회복을 기대하면서 단순 드레싱을 시행하였다.

전층 이식술은 서혜부에서 전층 피부를 취해(Fig. 1), 피하 지방 조직을 완전히 제거하고(Fig. 2), 전완 결손 부위에 얹고, 주변부 봉합과 몇 군데 중앙부 고정 봉합을 한 후, 진공을 이 용한 음압 상처 드레싱[KCI Medical Products(UK) LTD., Wimborne, Dorset, UK] (Fig. 3)을 적용하였다. 압력은 125 $\mathrm{mm} \mathrm{Hg}$, 간헐적인 모드(intermittent mode)로 설정하고 5일 간 유지하였다. 피부 이식이 잘 생착된 것을 확인한 후 봉합사 를 제거하였다(Fig. 4). 서혜부의 피부 공여부는 일차적으로 봉합하였다(Fig. 5).

두 군 간 나이, 성별, 전완 결손 부위의 크기 $\left(\mathrm{cm}^{2}\right)$, 가피나 궤 양, 혹은 육아 조직 등이 없이 수여부(전완부) 피부 이식이 완 전히 회복될 때까지 걸린 기간(일), 6개월이 지난 시점의 공여 부 합병증(비후성 피부, 통증, 가려움 등) 유무, 6개월이 지난 시점의 수여부(전완부)에 대한 Vancouver Scar Scale ${ }^{12)}$ (Table 1) 등을 조사하였다. Vancouver Scar Scale에 관한 조사는 2명 이상의 평가자에 의해 이중맹검법(double blind test)으로 시행 하였고, 관찰자 간 신뢰도(inter-observer reliability)를 평가하

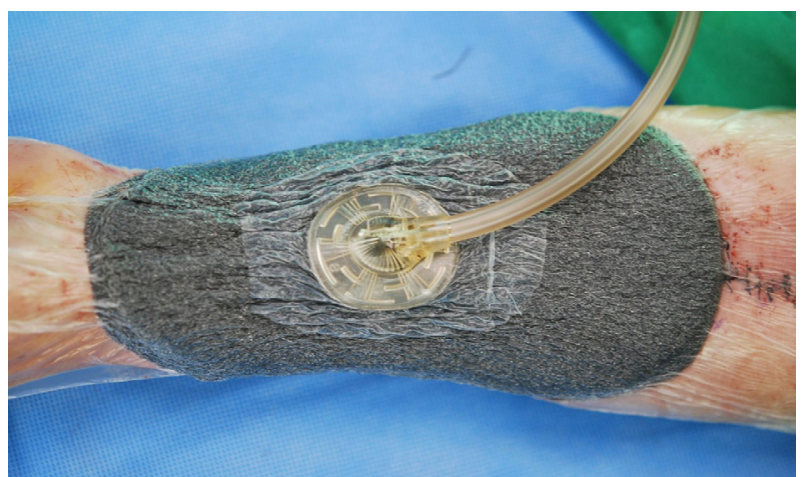

Fig. 3. The skin graft to the forearm is covered and pressed negatively by the vacuum-assisted closure system.

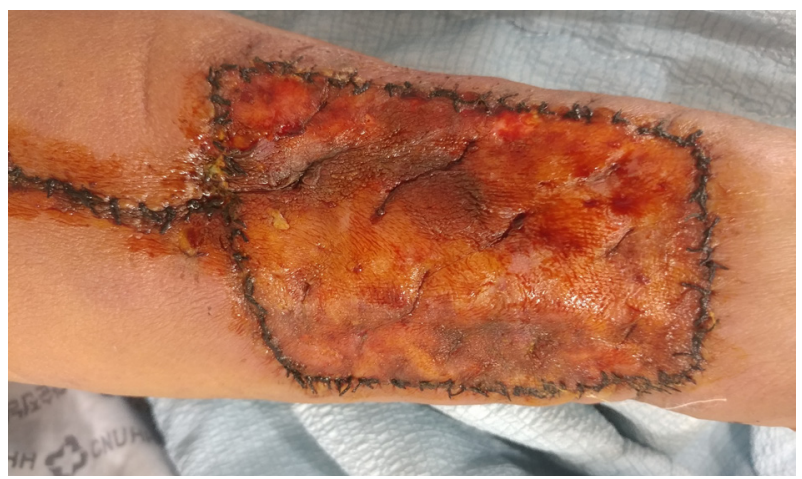

Fig. 4. The full-thickness skin is grafted successfully 7 days after the application of the vacuum-assisted closure system. 


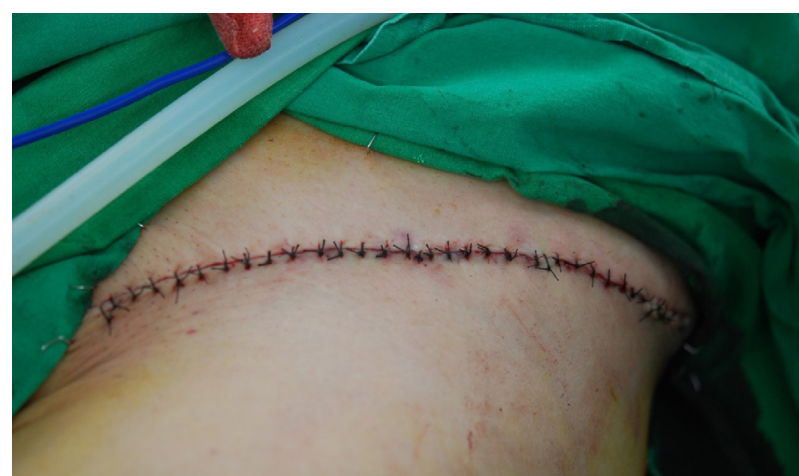

Fig. 5. The inguinal area is closed primarily after being taken of the full-thickness skin.

Table 1. The Vancouver Scar Scale

\begin{tabular}{cl}
\hline Pigmentation \\
0 & Normal \\
1 & Hypopigmentation \\
2 & Mixed pigmentation \\
3 & Hyperpigmentation \\
Pliability \\
0 & Normal \\
1 & Supple-flexible with minimal resistance \\
2 & Yielding-flexible with moderate resistance \\
3 & Firm-inflexible, resistance to manual pressure \\
4 & Banding-ropelike tissue that blanches \\
& with extension of the scar \\
5 & Contracture-permanent shortening of scar \\
Height & \\
0 & Flat \\
1 & $<2$ mm \\
2 & $<5$ mm \\
3 & $\geq 5$ mm \\
Vascularity \\
0 & Normal \\
1 & Pink \\
2 & Red \\
3 & Purple \\
\hline
\end{tabular}

였으며, 평가자 간 이견이 발생했을 때는 관찰자의 조사법을 훈련하거나 측정 범주를 조직화함으로써 조정하였다.

두 군 간의 통계분석은, 연속형 자료는 비모수검정(MannWhitney U test)으로, 범주형 자료는 Fisher의 정확 검정 (Fisher's exact test)을 이용하였고, $p$ 값이 0.05 미만일 때 유 의한 것으로 판정하였다.

\section{결 과}

피부이식은 부분층 이식술과 진공 음압 드레싱을 적용한 전 층 이식술(수 개월 후 주변 조직과 비슷할 정도로 회복된 모

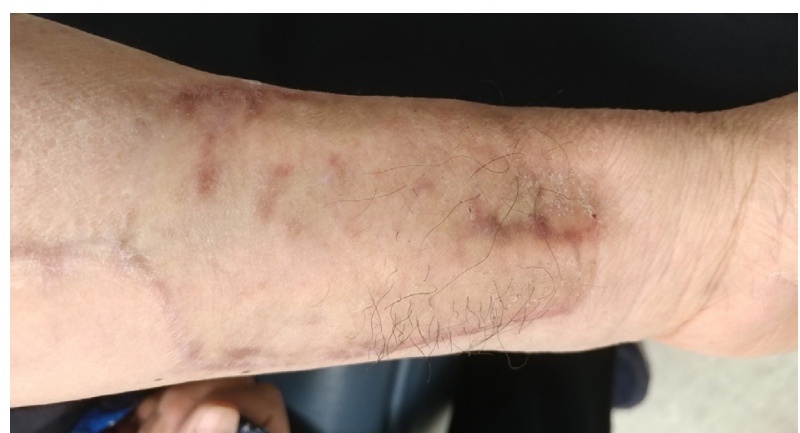

Fig. 6. The forearm is healed relatively well with the full-thickness skin graft applied with the vacuum-assisted closure system 6 months after the operation.

습)(Fig. 6)의 20예 모두 성공하였다. 부분층 이식군 10 명은 9 명이 남자였고, 1 명이 여자였으며, 평균 나이는 61.0세였다. 진 공 음압 드레싱을 적용한 전층 이식군(이하 전층 이식군) 10 명 은 9명이 남자였고, 1 명이 여자였으며, 평균 나이는 57.2세였다.

결손 부위 크기는 부분층 이식군에서 중위수(median)가 $92 \mathrm{~cm}^{2}$ (48 126), 전층 이식군에서는 $60 \mathrm{~cm}^{2}$ (40 77)로, 결손 부위가 큰 경우에 부분 이식층이 더 선호되는 경향을 보였다 $(p=0.049)$.

가피나 궤양, 혹은 육아 조직 등이 완전히 없어질 때까지의 수여부(전완부) 회복 기간은 부분층 이식군에서 중위수 44 일(28 109), 전층 이식군에서 중위수 31일(20 61)로, 전층 이 식군에서 더 빨리 회복되었지만, 통계적으로 유의하지는 않 았다 $(p=0.082)$.

공여부의 합병증은 부분층 이식군에서 5예 있었는데, 가 려움이 4예, 비후성 피부가 2예 있었으나(1예에서 가려움과 비후성 피부 모두 존재), 전층 이식군에서는 한 예도 없었다 $(p=0.033)$.

수여부(전완부)의 Vancouver Scar Scale은 먼저 착색도 (pigmentation)에서 부분층 이식군의 중위수가 2, 전층 이식군 의 중위수가 1 로, 전층 이식군에서 주변 피부와 색조가 더 비 슷하였다 $(p=0.037)$. 탄성도(pliability)에서는 부분층 이식군의 중위수가 2, 전층 이식군의 중위수가 1 로, 진공 음압 드레싱을 적용받은 전층 이식군이 더 탄력적이었다 $(p=0.009)$. 높이 (height)는 부분층 이식군의 중위수가 1 , 전층 이식군의 중위 수가 0 으로, 전층 이식군에서 주위 피부와 더 비슷한 높이를 나타내었다 $(p=0.014)$. 혈관성(vascularity)에서는 두 군의 중위 수가 1과 0.5 로, 통계학적으로 유의하지 않았다(Table 2). 문헌 보고 $^{2)}$ 와는 달리 두 군 모두 운동범위의 제한은 없었다.

\section{고 찰}

요측전완유리피판의 결손 부위를 재건하는 국내 보고로는 
Table 2. Comparison analysis between STSG group and FTSG group

\begin{tabular}{lccc}
\hline & STSG & FTSG & p-value \\
\hline Sex $(\mathrm{M}: \mathrm{F})$ & $9: 1$ & $9: 1$ & \\
Age $(\mathrm{yr})$ & 61.0 & 57.2 & \\
$\begin{array}{l}\text { Defect size } \\
\left(\mathrm{cm}^{2}, \text { median) }\right.\end{array}$ & $92(48-126)$ & $60(40-77)$ & 0.049 \\
$\begin{array}{c}\text { Days to complete } \\
\text { recovery (median) }\end{array}$ & $44(28-109)$ & $31(20-61)$ & 0.082 \\
$\begin{array}{c}\text { Complication on } \\
\text { donor site }\end{array}$ & 5 (4 pruritus, & 0 & 0.033 \\
$\begin{array}{l}\text { Vancouver Scar } \\
\text { Scale (median) }\end{array}$ & & & \\
$\quad \begin{array}{l}\text { Pigmentation } \\
\text { Pliability }\end{array}$ & 2.0 & & \\
$\quad$ Height & 2.0 & 1.0 & 0.037 \\
$\quad$ Vascularity & 1.0 & 1.0 & 0.009 \\
\hline
\end{tabular}

STSG: split-thickness skin graft, FTSG: full-thickness skin graft, M: male, F: female

Tae 등기이 자측(ulnar) 전진 피판으로 전완 결손 부위를 재건 하였고, Jeong 등 ${ }^{14}$ 은 전층 피부 이식술이 부분층 피부 이식 술보다 공여부의 합병증이 적고 미용적으로 더 좋다고 하였 다. 국외에서는 그동안 많은 연구들이 있었는데, 최근 Pabst 등흐는 1982년부터 2017년까지 1056개의 논문을 검색하여 메 타분석을 시행하였으며, 그 결과는 아래에 기술하였다.

부분층 이식술은 가장 흔한 방법으로서, 주로 앞쪽 대퇴부 에서 0.2 0.5 mm의 두께로 얻는다. 간단하고, 신뢰할 만하 며, 얻을 수 있는 부위도 대부분 제한이 없어, 연장된 요측전 완 결손 부위에 사용될 수 있다는 장점이 있다. 반면 단점으 로는 기능상 혹은 미용상 결과가 좋지 않다는 것인데, 특히 전완부 결손의 부피가 큰 경우에 두드러진다. 때로 피부 이식 을 위한 공여부에 통증이 동반되기도 한다. ${ }^{3)}$

전층 이식술은 $0.8 \sim 1.1 \mathrm{~mm}$ 의 두께로 얻는다. 최근 그 활 용도가 점점 높아지고 있다. 기능상, 미용상 결과가 좋다는 것이 장점인 반면, 공여부를 봉합해야 하기 때문에 이용될 수 있는 면적이 제한된다는 단점이 있다. 피하 지방 조직을 완전히 제거하는 것이 필수인데, 그 이유는 전층 피부 이식이 전완에 얹어졌을 때 기저부 조직에서 충분히 영양 공급을 받 아야 하기 때문이다. ${ }^{3)}$

위 두 가지 방법, 즉 부분층과 전층 이식술을 서로 비교하 자면, 전층 이식술이 미용적으로 더 우수하고, ${ }^{8)}$ 피부 이식을 위한 공여부를 일차적으로 봉합하기 때문에 통증이 덜하 고,") 술 후 연축도 적어 손가락과 손목의 움직임에도 유리하 다고 알려져 있다. ${ }^{15,16)}$ 본 연구에서도 전층 이식군이 전완의 회복 기간, 공여부의 합병증, Vancouver Scar Scale 비교에 서 더 좋은 결과를 나타내었다. 두껍게 얻어진 조직이 전완 의 건의 보호와 결손 부피의 최소화에 기여한 것으로 사료된
다. 본 연구와 기존의 전층 이식술 연구들과 차별점이 있다 면, 본 연구에서는 음압 상처 드레싱을 적용했다는 것이다.

문헌에 따르면 전완 결손 부위가 큰 경우에 전층보다는 부 분층 이식술이 더 선호되는데, ${ }^{3)}$ 본 연구에서도 전층 이식은 $77 \mathrm{~cm}^{2}$ 의 결손까지 이용되었으나 $126 \mathrm{~cm}^{2}$ 의 큰 결손에는 부 분층 이식술이 사용되었다.

본 연구에 몇 가지 제한점이 있다. 음압 상처 드레싱을 적 용하는 면에서 두 군을 비교하는 조건이 같지 않았다. 대상 군의 수가 적은 것도 큰 제한점이다. 향후 이러한 사항을 보 완한 연구가 필요하겠다.

본 연구자가 부분층 이식술에 음압 상처 드레싱을 적용하 지 않은 이유는 고식적인 정적 압박 드레싱이 매우 효과적이 었기 때문이었다.

진공을 이용한 음압 상처 드레싱을 적용한 서혜부에서 채 취한 전층 피부이식술은 비록 부분층 이식술보다 작은 결손 부위에 이용이 되지만 요측전완유리피판의 결손 부위를 재 건하는데 많은 장점이 있다.

\section{Acknowledgments}

This was presented at the International Congress of ORL-HNS 2018

\section{ORCID}

Joon-Kyoo Lee https://orcid.org/0000-0002-7542-9616

\section{REFERENCES}

1) Benateau H, Laraba C, Alix T, Compere JF. Radial forearm or Chinese flap. Rev Stomatol Chir Maxillofac 2002;103(1):35-40.

2) Richardson D, Fisher SE, Vaughan ED, Brown JS. Radial forearm flap donor-site complications and morbidity: A prospective study. Plast Reconstr Surg 1997;99(1):109-15.

3) Pabst AM, Werkmeister R, Steegmann J, Hölzle F, Bartella A. Is there an ideal way to close the donor site of radial forearm free flaps? Br J Oral Maxillofac Surg 2018;56(6):444-52.

4) Yun TK, Yoon ES, Ahn DS, Park SH, Lee BI, Kim HS, et al. Stabilizing morbidity and predicting the aesthetic results of radial forearm free flap donor sites. Arch Plast Surg 2015;42(6):769-75.

5) Wester JL, Pittman AL, Lindau RH, Wax MK. AlloDerm with split-thickness skin graft for coverage of the forearm free flap donor site. Otolaryngol Head Neck Surg 2014;150(1):47-52.

6) Olson MD, Moore EJ, Price DL. Removal of the split thickness skin graft from the skin paddle of the donor site: A single institution's experience. Am J Otolaryngol 2015;36(6):820-2.

7) Kim TB, Moe KS, Eisele DW, Orloff LA, Wang SJ. Full-thickness skin graft from the groin for coverage of the radial forearm free flap donor site. Am J Otolaryngol 2007;28(5):325-9.

8) Zuidam JM, Coert JH, Hofer SO. Closure of the donor site of the free radial forearm flap: A comparison of full-thickness graft and split-thickness skin graft. Ann Plast Surg 2005;55(6):612-6.

9) Andrews BT, Smith RB, Chang KE, Scharpf J, Goldstein DP, Funk GF. Management of the radial forearm free flap donor site with the vacuum-assisted closure (VAC) system. Laryngoscope 2006;116(10):1918-22

10) Chio EG, Agrawal A. A randomized, prospective, controlled study 
of forearm donor site healing when using a vacuum dressing. Otolaryngol Head Neck Surg 2010;142(2):174-8.

11) Koch M, Jalyzada K, Grundtner P, Iro H, Scherl C, Harréus U, et al. Treatment of the donor site of free radial flaps: Vacuum sealing versus conventional wound care. Acta Otolaryngol 2017;137(12): 1301-6.

12) Baryza MJ, Baryza GA. The Vancouver scar scale: An administration tool and its interrater reliability. J Burn Care Rehabil 1995;16(5):535-8.

13) Tae K, Lee HS, Kim HS, Ahn HC. The closure of radial forearm flap donor site using local ulnar advancement flap. Korean J Head
Neck Oncol 1998;41(6):778-82.

14) Jeong WS, Choi JW, Oh TS. Comparison study between coverage choices for radial forearm free flap donor site. Korean J Head Neck Oncol 2015;31(1):5-8.

15) Ito O, Igawa HH, Suzuki S, Muneuchi G, Kawazoe T, Saso Y, et al. Evaluation of the donor site in patients who underwent reconstruction with a free radial forearm flap. J Reconstr Microsurg 2005;21(2): 113-7.

16) Ho T, Couch M, Carson K, Schimberg A, Manley K, Byrne PJ. Radial forearm free flap donor site outcomes comparison by closure methods. Otolaryngol Head Neck Surg 2006;134(2):309-15. 